\title{
PERANCANGAN MOTION GRAPHIC DAMPAK PLASTIK DI LAUT
}

\author{
Eduard Bagas Pratama ${ }^{1}$, Donna Carollina ${ }^{2}$ \\ ${ }^{1}$ Sekolah Tinggi Seni Rupa dan Desain Visi Indonesia \\ ${ }^{2}$ Sekolah Tinggi Seni Rupa dan Desain Visi Indonesia \\ E-mail: edubagas01@gmail.com ${ }^{1}$,donnacarollina@yahoo.com²
}

\begin{tabular}{|c|c|}
\hline ARTICLE INFO & ABSTRAK \\
\hline $\begin{array}{l}\text { Article history: } \\
\text { Received: } 15 \text { September } 2020 \\
\text { Revised: } 30 \text { September } 2020 \\
\text { Accepted: } 07 \text { Oktober } 2020\end{array}$ & \multirow{2}{*}{$\begin{array}{l}\text { Discussion about the problem of world waste, especially plastic waste } \\
\text { in the sea, is currently a seriously problem, especially in Indonesia. } \\
\text { Indonesia is the second-largest contributor to plastic waste in the } \\
\text { world. Plastic waste in the sea takes } 500-1000 \text { years to completely } \\
\text { decompose. So that efforts need to be made to reduce the use of } \\
\text { plastic to prevent the destruction of Indonesia's marine ecosystem. } \\
\text { The effort made by the writer is to design motion graphics. Motion } \\
\text { graphics become an educational medium for junior high school } \\
\text { children about the impact of plastic in the ocean along with solutions } \\
\text { that can be applied in everyday life. }\end{array}$} \\
\hline $\begin{array}{l}\text { Keywords: } \\
\text { Motion graphic } \\
\text { The impact of plastic waste }\end{array}$ & \\
\hline
\end{tabular}

\section{PENDAHULUAN}

Permasalahan sampah menjadi masalah serius yang gencar di bahas di dunia saat ini terutama persoalan sampah plastik, sampah plastik sangat sulit terurai dan membutuhkan waktu 500-1000 tahun bagi plastik untuk benar-benar terurai. Masalah ini pun berlaku bagi Indonesia, dimana menurut hasil riset yang dilakukan pada 13 Februari 2015 lalu mengungkap bahwa Indonesia menjadi salah satu negara penghasil sampah terbesar kedua di dunia (Utomo, 2016). Hal ini cukup ironis mengingat Indonesia merupakan negara kepulauan yang dikelilingi oleh laut. Dimana masyarakatnya banyak mengandalkan keberagaman ekosistem laut sebagai sumber ekonomi dan pangan.

Negara-negara maju lainnya seperti Amerika, Jepang dan Italia sudah melakukan berbagai upaya untuk mengatasi masalah sampah plastik ini. Amerika dan Jepang membuat mesin penghancur botol plastik secara otomatis dan bisa menghasilkan uang bahkan di Italia mereka menukar botol plastik satu karung penuh dengan tiket kereta api tanpa syarat. Di Indonesia sendiri upaya yang dilakukan untuk mengatasi masalah sampah plastik adalah lewat Bank Sampah, namun dengan beragam hambatan dari segi pembiayaan, regulasi, dan peran serta 
masyarakat yang kurang optimal kinerja Bank Sampah dirasa kurang efektif, hal ini seperti yang dipaparkan dalam dalam sebuah penelitian Efektivitas Pengelolaan Bank Sampah dengan Studi Kasus Bank Sampah Malang (BSM) (Suryani, 2014). Sedangkan di Bali sendiri mereka sudah membeli beberapa mesin penghancur botol plastik dari Jepang dan akan memberikan uang untuk setiap botol plastik yang dihancurkan.

Dari seluruh upaya yang dilakukan, peran sebagian besar masyarakat Indonesia masih kurang optimal. Hal ini tampak dari perilaku tidak peduli dan tetap membuang sampah sembarangan terutama di sungai, dimana sampah yang dibuang ke sungai akan bermuara sampai ke laut dan yang terkena dampaknya adalah hewan-hewan yang ada di lautan. Bukan hanya membuat laut kotor namun juga mengancam ekosistem hewan laut karena hewan laut akan memakan plastik tersebut. Hal ini dapat ditemukan seperti pada kasus Paus mati yang terdampar di perairan Pulau Kapota, Taman Nasional Wakatobi, Sulawesi Tenggara pada November 2018 lalu, dimana dalam perut paus tersebut ditemukan 5,9 kg sampah plastik (BBC News Indonesia, 2018). Ahli ekologi mikroba di Royal Netherlands Institute for Sea Reseach berkata bahwa sampah plastik yang ada di dalam laut maupun di pantai memiliki bau seperti ikan (Zettler et al., 2013). Semua plastik di dalam laut ditutupi dengan lapisan tipis mikroba yang disebut Plastisphere, lapisan ini mengeluarkan senyawa kimiawi yaitu bau dan rasanya seperti makanan binatang laut, ada senyawa khusus yaitu Dimethyl Sulfide (DMS) yang diketahui sebagai kode kimiawi plastik dan dikenal menarik perhatian sejumlah biota laut. Bila situasi dan kondisi ini diabaikan dapat diprediksi ekosistem laut di laut Indonesia akan rusak dan menuju kepunahan karena dampak buruk dari sampah plastik.

Berangkat dari permasalahan sampah laut di Indonesia tersebut, penulis tergerak membuat sebuah perencanaan kampanye periklanan untuk mengurangi penggunaan plastik sekali pakai dan mengedukasi mengenai dampak yang diakibatkan dari plastik sendiri bagi hewan di laut. Kampanye tersebut dalam bentuk motion graphic yang ditujukan untuk anak SMP laki-laki. Remaja SMP adalah target audiens yang cocok dalam perancangan motion graphic ini karena mereka sedang dalam masa pertumbuhan dan memiliki rasa ingin tahu dan tingkat kepedulian yang tinggi. Karakteristik motion graphic sendiri dapat membuat target audiens menjadi lebih tertarik, memudahkan dalam belajar dan menangkap informasi serta dapat menumbuhkan rasa ingin tahu siswa. Secara psikologis warna yang menyenangkan dan style gambar kartun yang simpel dapat mendorong minat belajar remaja dan memudahkan target untuk menangkap informasi. Selain itu remaja pada saat ini lebih senang menonton video daripada membaca buku, sehingga penggunaan motion graphic sebagai media edukasi dirasa tepat. Hal ini pun di dukung 
dari penelitian yang menguji kelayakan pengembangan media pembelajaran motion graphic untuk siswa dimana hasil dari uji kelayakan tersebut adalah motion graphic layak untuk digunakan sebagai media pembelajaran (Damayanti \& Wulandari, 2018).

Karakteristik motion graphic yang informatif, menarik dan juga menghibur dengan adanya konten visual seperti gambar, teks dan diberi warna-warna yang dapat menarik, ditambah dengan suara dan musik yang dapat mengubah suasana hati, dipadukan dengan gerakan (motion) memberikan kesan dinamis, dapat menambah pemaknaan dan efektifitas atas informasi yang disampaikan. Penyampaian informasi menggunakkan penjelasan yang logis dan informasi yang disampaikan berdasarkan fakta dan penelitian sehingga diharapkan target audiens mau menerima, meresapi dan bertindak sesuai dengan informasi yang telah disampaikan.

Motion graphic adalah media yang digunakan oleh desainer grafis profesional untuk menggambarkan serta memberikan suatu masalah yang ada lalu mengkomunikasikan kepada audiens dalam bentuk video berbasis animasi 2 dimensi. Pesan pada gambar mampu mempersuasi seseorang dalam menentukan sikap untuk memilih tindakan yang menunjang keinginannya (Kusumadinata et al., 2019). Sistem pembelajaran berbasis ponsel pintar mampu meningkatkan kapasitas siswa dalam menerima informasi secara simultan serta memberi dampak kesenangan sehingga siswa mampu memacu dirinya untuk menggali informasi (Prayogi R, Suryatna U, 2015). Kemampuan remaja dalam penggunaan media sosial memiliki kategori yang sangat baik yang berarti memiliki keahlian yang mampu menggunakan alat tersebut sebagai hiburan namun juga untuk melakukan kegiatan yang lebih seperti halnya promosi dan pendidikan (Rahmah M, Sukarelawati, 2018). Demikian berdasarkan paparan tersebut penggunaan media motion graphic didukung dengan penggunaan media sosial sebagai medium untuk penyebaran konten dapat menjadi media edukasi bagi target audiens dalam mengurangi sampah plastik dan dampak yang dihasilkan di laut.

\section{METODE PERANCANGAN}

Perancangan motion graphic dilakukan dengan menggunakan metode pengumpulan data lewat observasi serta tinjauan pustaka. Kemudian masuk kepada bagian perancangan yang dimulai dengan membuat sinopsis, naskah, storyboard, dan kemudian memvisualisasikannya menjadi sebuah motion graphic yang siap untuk didistribusikan kepada target audiens. 


\section{PEMBAHASAN}

\subsection{Deskripsi Data}

\subsubsection{Plastik}

Plastik adalah suatu polimer yang mempunyai sifat-sifat unik dan luar biasa, sedangkan polimer adalah suatu bahan yang terdiri dari unit molekul yang disebut monomer. Polimer alam yang telah dikenal antara lain: selulosa, protein, karet alam, dan sejenisnya. Plastik yang dibuat secara komersial pertama kali adalah nitroselulosa yang kemudian berkembang dan berperan penting dalam bidang elektronika, tekstil, pertanian, transportasi, konstruksi, furniture, dan produk industri lainnya (Mujiarto, 2005).

\subsubsection{Motion Graphic}

Motion adalah bahasa universal, setiap gerakan mempunyai dampak dan memilih metode untuk memindahkan elemen dalam sebuah layar akan meningkatkan maknanya. Penggunaan motion graphic membantu untuk menyederhanakan pesan dari isi yang dibawa oleh data utama. Memecah seluruh data ke dalam beberapa bagian benar-benar membantu untuk menyajikan informasi dalam bagian kecil tapi pada akhirnya itu adalah cara yang menarik dan sederhana untuk menunjukkan informasi (Krasner, 2008). Untuk membuat motion graphic yang efektif diperlukan untjuk mempertimbangkan antara lain (ibid, 2008):

a. Spatial: Pertimbangan ruang seperti posisi, ukuran, arah acuan, arah gerakan, gerakan yang dipengaruhi gerakan lainnya, hubungan pergerakan dengan batas-batas frame, faktor-faktor tersebut penting untuk dipertimbangkan ketika proses koreografi animasi. Selain itu, gerakan frame yang diciptakan oleh fisik atau simulasi kamera dapat menentukan bagaimana ruang yang dilihat dan ditafsirkan dalam environment digital.

b. Temporal: Pertimbangan temporal terdiri dari waktu dan velocity. Koreografi motion memerlukan pemahaman mendasar tentang bagaimana waktu diukur. Tergantung pada apakah yang sedang merancang untuk film, video, atau media digital, masing-masing format memiliki standar sendiri untuk mengukur waktu. Velocity adalah kecepatan di mana unsur-unsur bergerak atau berubah dari waktu ke waktu dan ruang. Ini adalah faktor yang menentukan cukup dalam mencapai dinamis, animasi manusia hidup. Seperti arah, kecepatan dapat linear atau nonlinear. Gerakan linier dapat diterapkan untuk presentasi motion graphic yang dimaksudkan untuk melihat cairan atau mekanis. Sedangkan gerakan nonlinear biasanya diperuntukan makhluk hidup. Dalam motion graphic, teknik gerakan lambat dan cepat, reverse, playback, dan freeze-frame yang 
efektif untuk menekankan dan melebih-lebihkan tindakan. Mereka juga dapat mendukung irama yang mendasari, berkontribusi terhadap suasana hati, dan mengubah pengertian kita tentang waktu obyektif dan subyektif.

c. Live action: Faktor-faktor yang harus dipertimbangkan ketika bekerja dengan live-action konten termasuk bentuk atau konteks proyek property film, dan sifat sinematik, seperti tone, contrast, lighting, depth off field, focus, camera angle, shot size, dan mobile framing.

d. Typographic: Peran tipografi ekspresif kinetik adalah untuk mewakili konsep di format visual. Dapat menyampaikan emosi melalui dampak grafis yang unik dan gerakan dalam ruang.

\subsubsection{Target Audiens Media}

a. Berdasarkan letak geografis adalah masyarakat Indonesia.

b. Berdasarkan karakteristik demografis adalah: (1) Laki-laki; (2) Berusia 13-15 tahun; (3) Sedang duduk di bangku Sekolah Menengah Pertama (SMP); dan (4) Strata ekonomi sosial menengah.

c. Berdasarkan kondisi psikografis: (1) Masih dalam tahap pencarian jati diri; (2) Memililki rasa kepedulian terhadap lingkungan terutama sampah plastik; (3) Menyukai hal yang dilakukan bersama (kolektif); dan (4) Memiliki kebebasan berekspresi.

d. Berdasarkan perilaku (behaviour): (1) Suka meluangkan waktu untuk streaming video; dan (2) Peduli terhadap lingkungan sekitar.

\subsection{Pembahasan}

\subsubsection{Naskah/Script}

\begin{tabular}{|l|l|l|}
\hline$\# 1$ & Intro & $\begin{array}{l}\text { Hi guys, kalian tau gak sih masalah tentang plastik yang lagi gencar } \\
\text { saat ini ? Ternyata itu bukan hoax loh! Sampah menjadi masalah } \\
\text { yang sangat serius bagi ekosistem laut. Kok bisa? Yuk teliti lebih } \\
\text { detail tentang masalahnya! }\end{array}$ \\
\hline \#2 & Apa itu plastik? & $\begin{array}{l}\text { Jadi plastik itu terbuat dari polymer yang panjang dan saling } \\
\text { menyambung. Namun seiring berjalannya waktu ilmuwan } \\
\text { menemukan polymer jenis baru yaitu synthetic polymer yang } \\
\text { mempunyai sifat ringan, kuat, elastis, mudah dibentuk, tahan lama } \\
\text { dan mudah ditemukan dimana aja. Tapi dari semua bahan yang ada, } \\
\text { plastik adalah bahan yang paling sulit terurai, dibutuhkan 500-1000 } \\
\text { tahun untuk benar-benar terurai loh. }\end{array}$ \\
\hline \#3 & Data & $\begin{array}{l}\text { Terus emang plastik itu kemana aja sih setelah dipakai? Plastik di } \\
\text { dunia hanya 9\% yang didaur ulang, kemudian 12\% dibakar dan } \\
79 \% \text { masih utuh. Dari 79\% tersebut sudah 8 juta ton plastik/tahun }\end{array}$ \\
\hline
\end{tabular}




\begin{tabular}{|l|l|l|}
\hline & & $\begin{array}{l}\text { yang tersebar di laut. Terus kalo di Indonesia gimana? Kalo di } \\
\text { Indonesia sih udah 3,2 juta ton/tahun dan itu terus meningkat loh! } \\
\text { Kabar buruknya nih Indonesia itu jadi negara kedua penyumbang } \\
\text { sampah plastik terbanyak kedua di dunia setelah China. }\end{array}$ \\
\hline$\# 4$ & Plastik di lautan & $\begin{array}{l}\text { Terus apa dampaknya plastik kalo mengapung di lautan? Jadi, } \\
\text { sampah plastik yang mengapung di lautan itu akan terkena sinar UV } \\
\text { dan kemudian plastik tersebut menjadi partikel-partikel kecil yang } \\
\text { disebut mikroplastik. }\end{array}$ \\
\hline$\# 5$ & Mikroplastik & $\begin{array}{l}\text { Mikroplastik berukuran kurang dari 0,5 mm. Dan semua hewan di } \\
\text { laut pasti memakan mikroplastik tersebut karena ukurannya yang } \\
\text { sangat kecil sedangkan hewan tidak bisa mencerna plastik tersebut } \\
\text { di perut mereka dan akan mengendap di perut mereka selamanya } \\
\text { dan mati. }\end{array}$ \\
\hline$\# 6$ & Kasus & $\begin{array}{l}\text { Dan kasus hewan-hewan mati sudah banyak ditemukan, contohnya } \\
\text { di tahun 2016 kemarin paus sperma terdampar di sulawesi namun } \\
\text { perutnya penuh dengan sampah plastik. Di Itali paus sperma } \\
\text { tedampar juga dan perut paus sperma penuh dengan sampah seberat } \\
\text { 22 kilo! } \\
\text { Data di Konferensi Laut PBB di New York tahun 2017 menyebut, } \\
\text { limbah plastik di laut telah membunuh 1 juta burung laut dan lebih } \\
\text { dari 100 ribu mamalia laut dan ikan yang tak terhitung jumlahnya. }\end{array}$ \\
\hline \#8 & $\begin{array}{l}\text { Nah jadi itu tadi guys dampak dari plastik yang ada dilaut. Oh iya, } \\
\text { di tahun 2050 bakal diperkirakan lebih banyak sampah plastik } \\
\text { daripada ikan di lautan, duhh sedihnyaa. Gak mau kan itu terjadi? } \\
\text { Yuk bareng-bareng mengurangi sampah plastik dengan mengurangi } \\
\text { penggunaan plastik. }\end{array}$ \\
\hline Sction & $\begin{array}{l}\text { Solusinya yaitu kita harus mengurangi penggunaan plastik sekali } \\
\text { pakai, gampang kok! Buat kalian yang suka beli thai tea nih, bawa } \\
\text { aja botol plastik yang bisa dipake berkali kali dari rumah buat } \\
\text { wadahnya, terus kotak makan, pakai tas belanja/totebag, pakai } \\
\text { sedotan stainless atau bambu juga bisa! }\end{array}$ \\
\hline $\begin{array}{l}\text { Yang kamu lakukan itu penting dan sangat berguna kok! Dimulai } \\
\text { dari sendiri terus ajak temen dan keluarga dan bayangin kalo temen } \\
\text { dan keluarga yg kalian ajak itu ngajak yang lain juga. Jadi banyak } \\
\text { kan yang ngelakuin? Hehe yuk kurangi sampah plastik, bersama } \\
\text { kita bisa! }\end{array}$ \\
\hline Closing
\end{tabular}

Tabel 1.Naskah/script

(Sumber: Dokumentasi penulis) 


\subsubsection{Konsep Visual: Set dan Background}

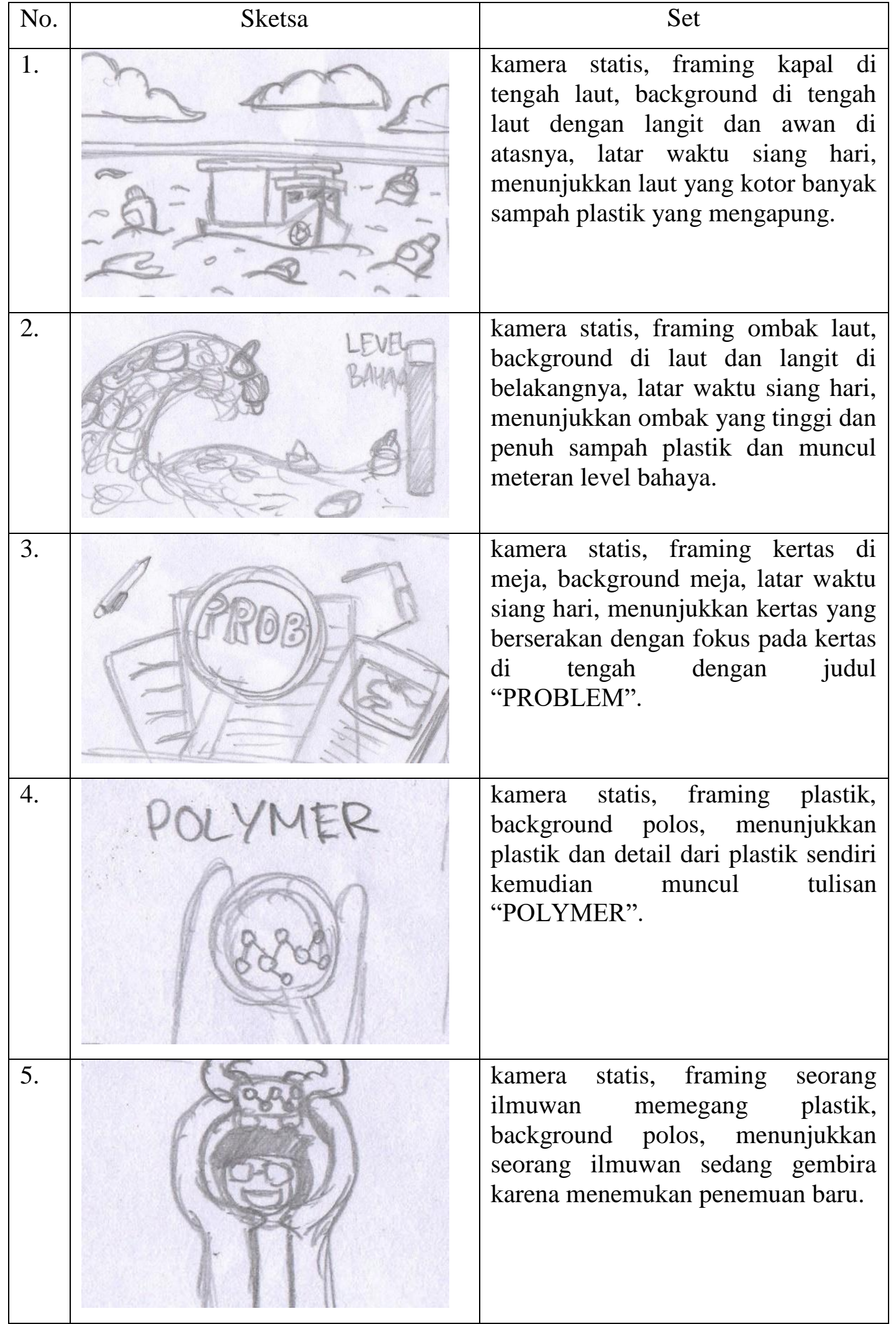




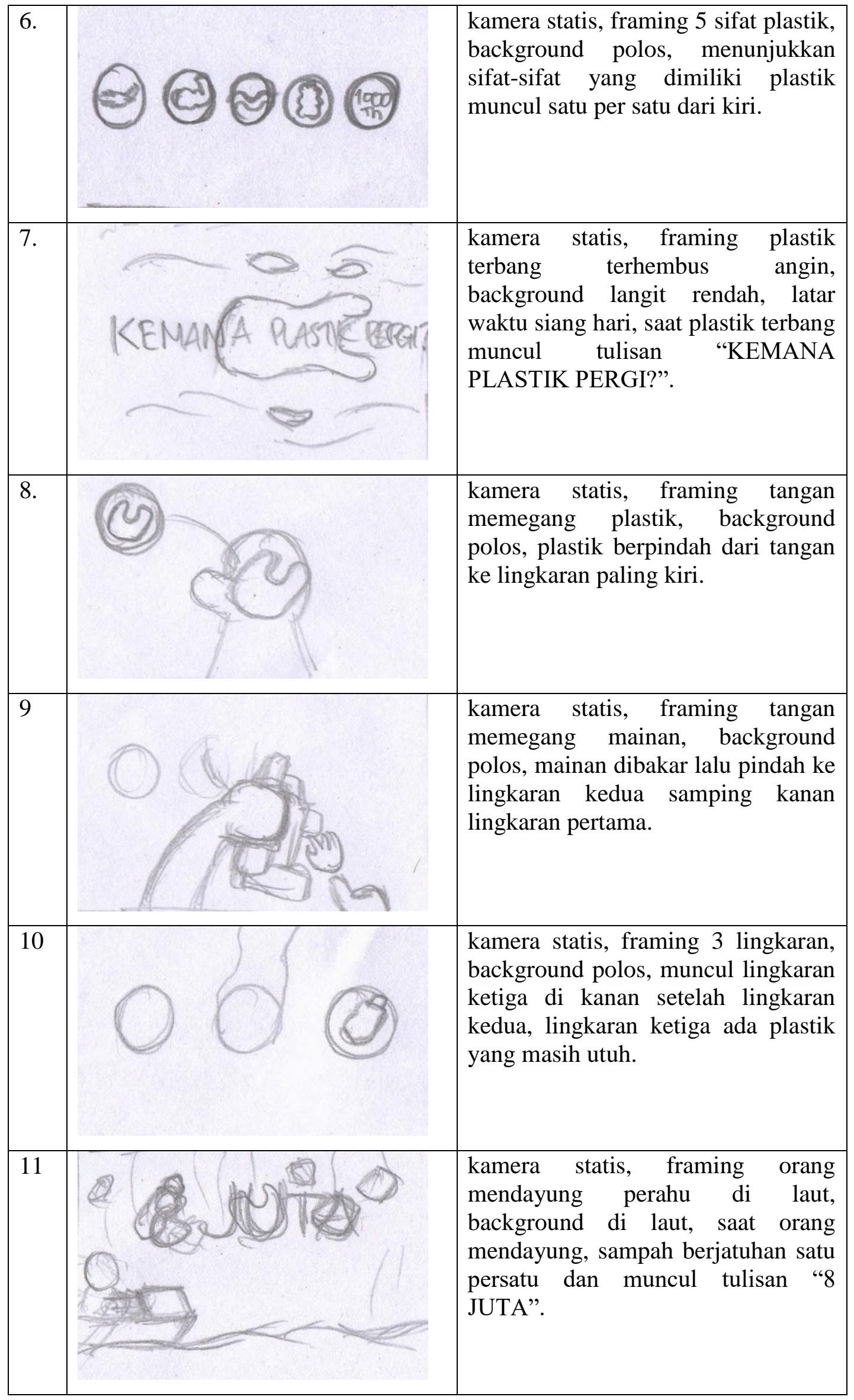




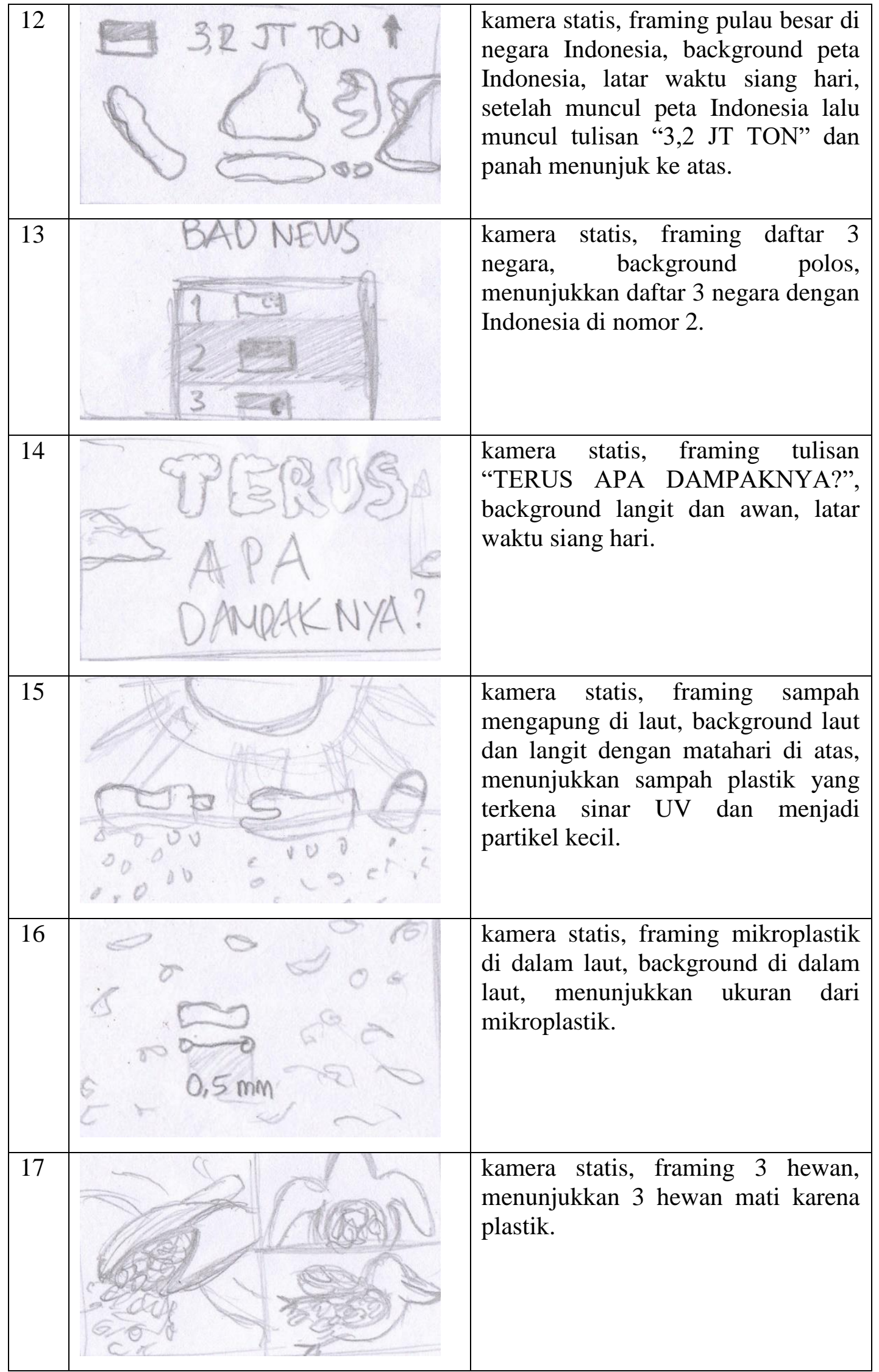




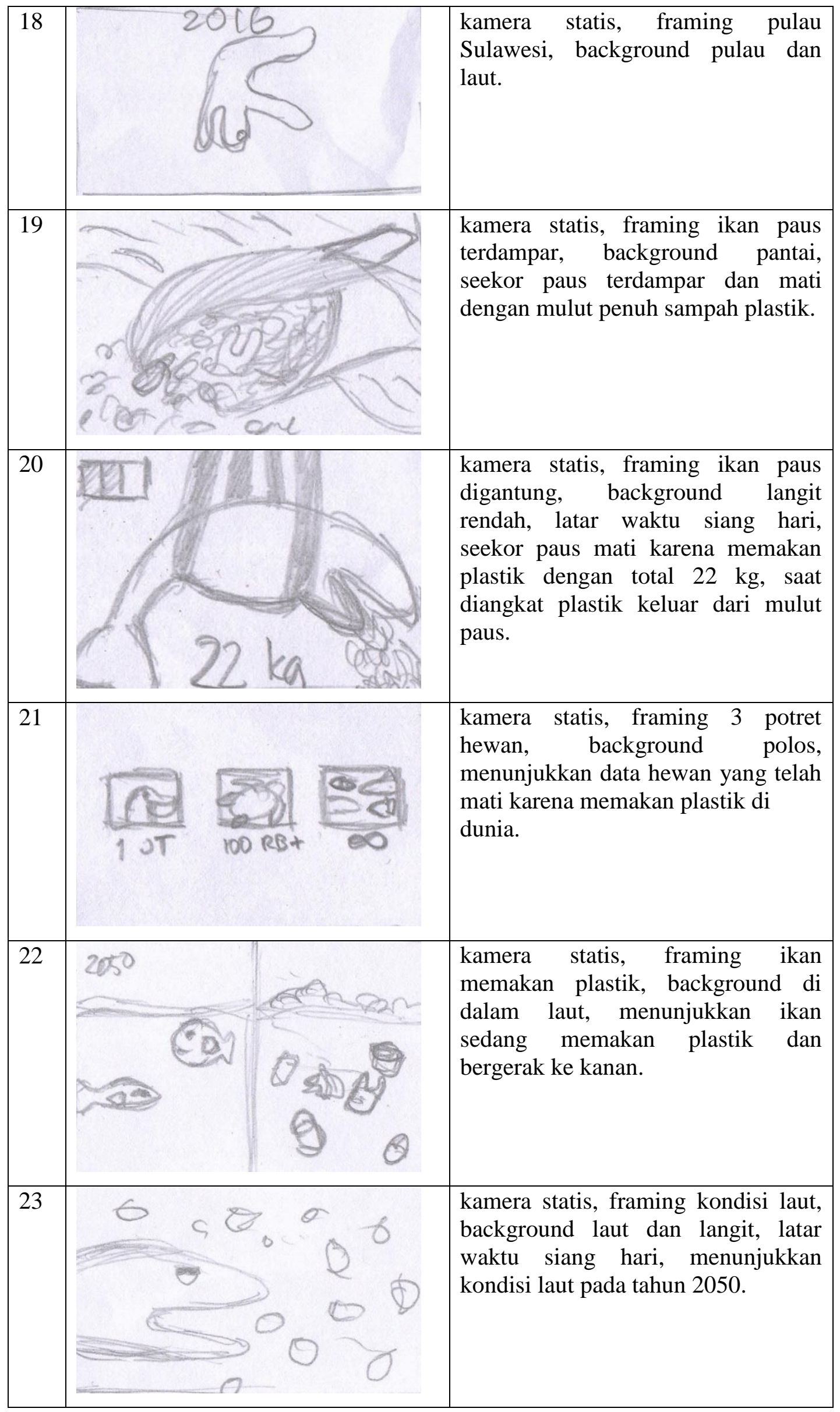




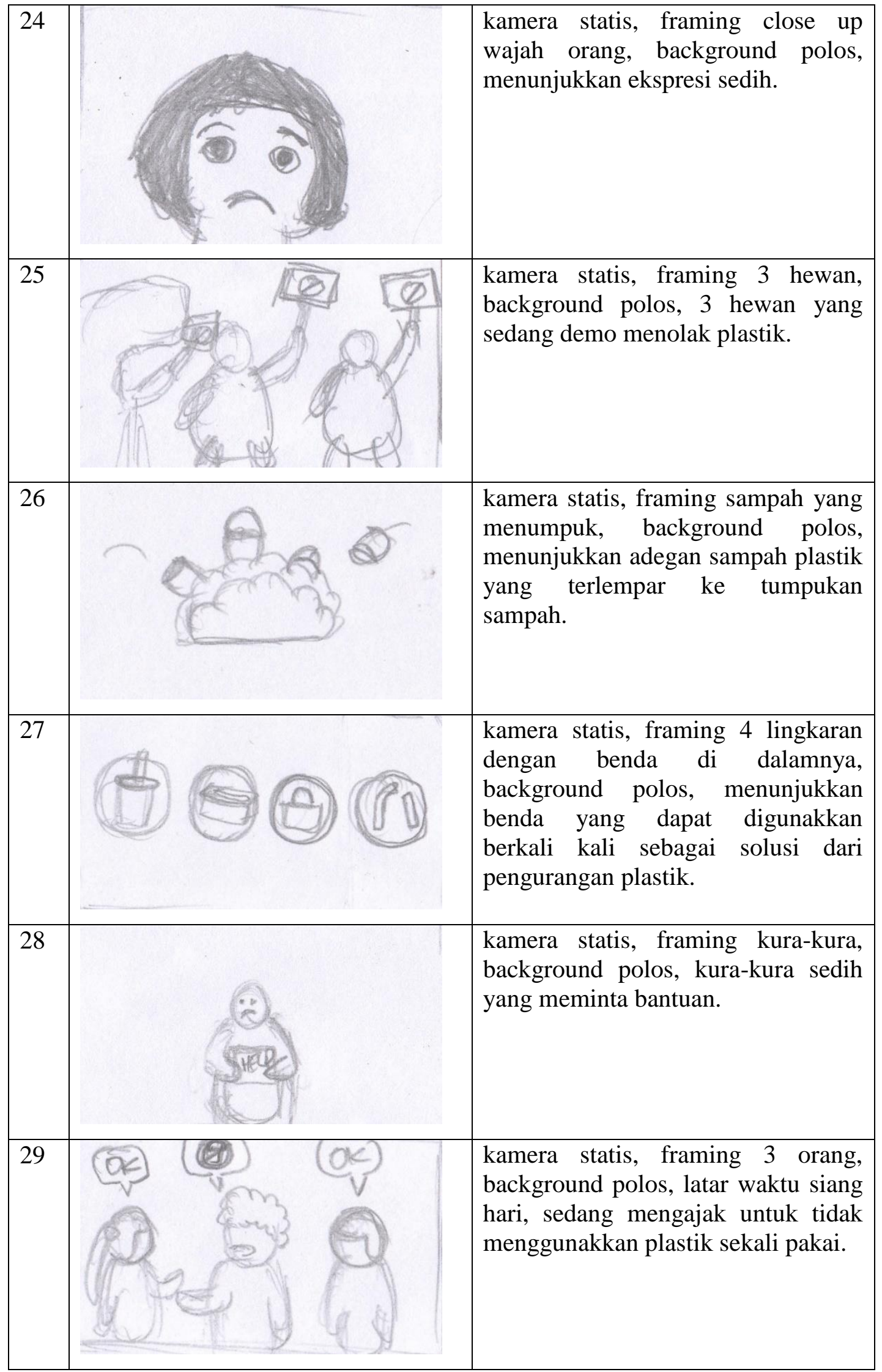




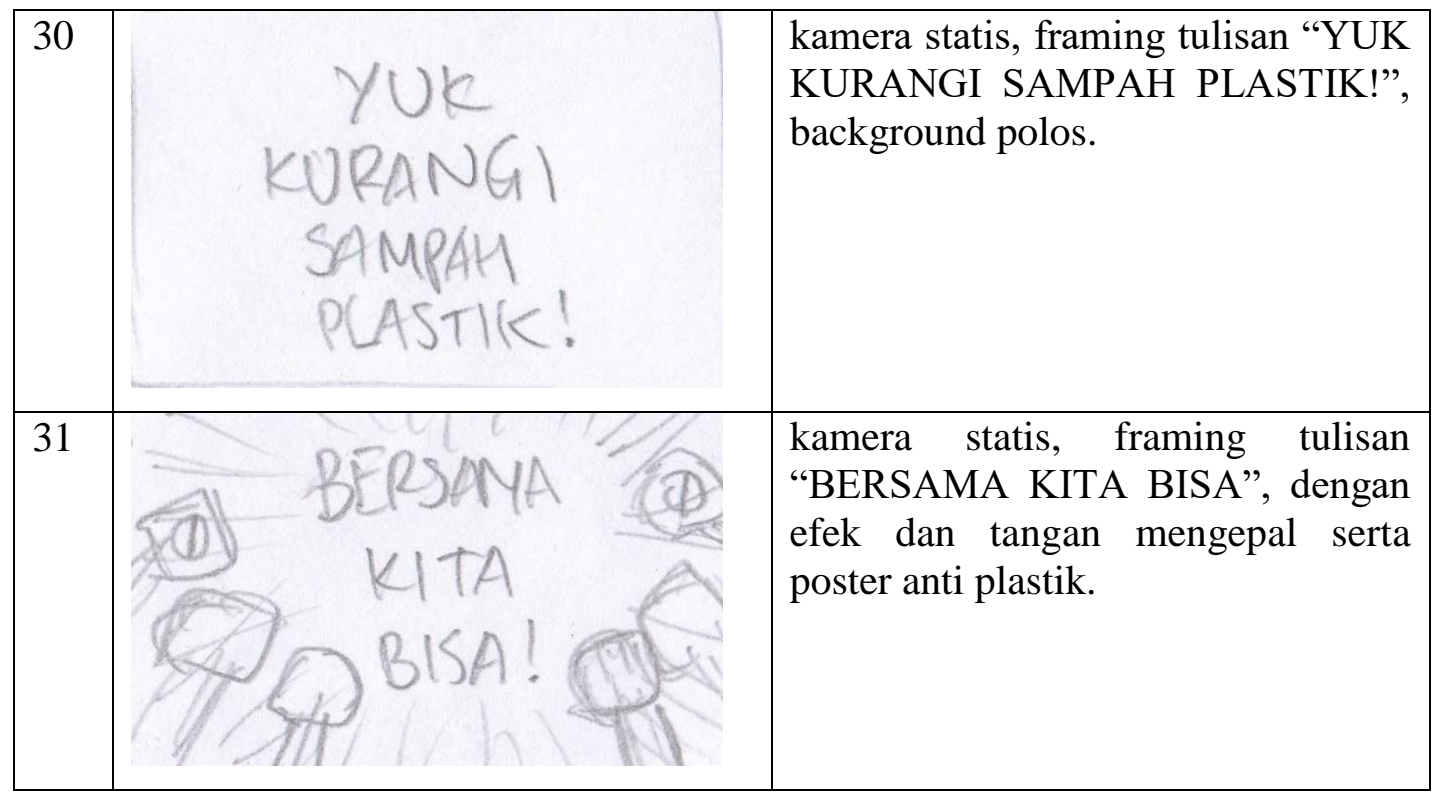

Tabel 2. Set dan background

(Sumber: Dokumentasi penulis)

\subsubsection{Konsep Visual: Tipografi}

Karakter jenis tipografi dari gaya desain Modern dari motion graphic lebih memicu gaya yang sans-serif dan simple. Jenis ini akan memperkuat kesan modern dan kuatnya informasi yang disampaikan melalui motion graphic, font yang dipakai adalah Montserrat.

\section{Aa Bb Cc Dd Ee Ff Gg Hh li Jj Kk} LI Mm Nn Oo Pp Qq Rr Ss Tt Uu Vv

Ww Xx Yy Zz áçêñöùš

\section{?!\&@\$€ 0123456789}

Gambar 1. Monsterrat Font

(Sumber: www.1001font.com) 


\subsubsection{Konsep Visual: Teknik Visualisasi}

Teknik visualisasi yang akan digunakan pada perancangan ini adalah visualisasi 2D dengan style gambar flat design yang menggunakan warna-warna neon dan kontras sesuai dengan target audiens perancangan ini.

\subsubsection{Desain Judul / Titling and Credit Design}
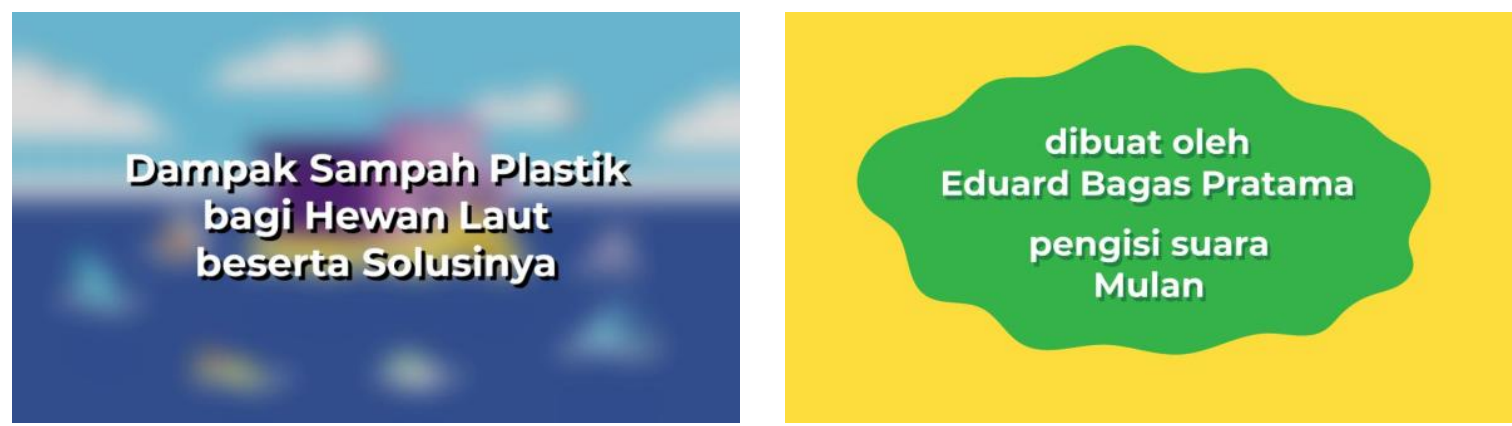

Gambar 2. Desain judul dan credit

(Sumber: Dokumentasi penulis)

\subsubsection{Visualiasi}
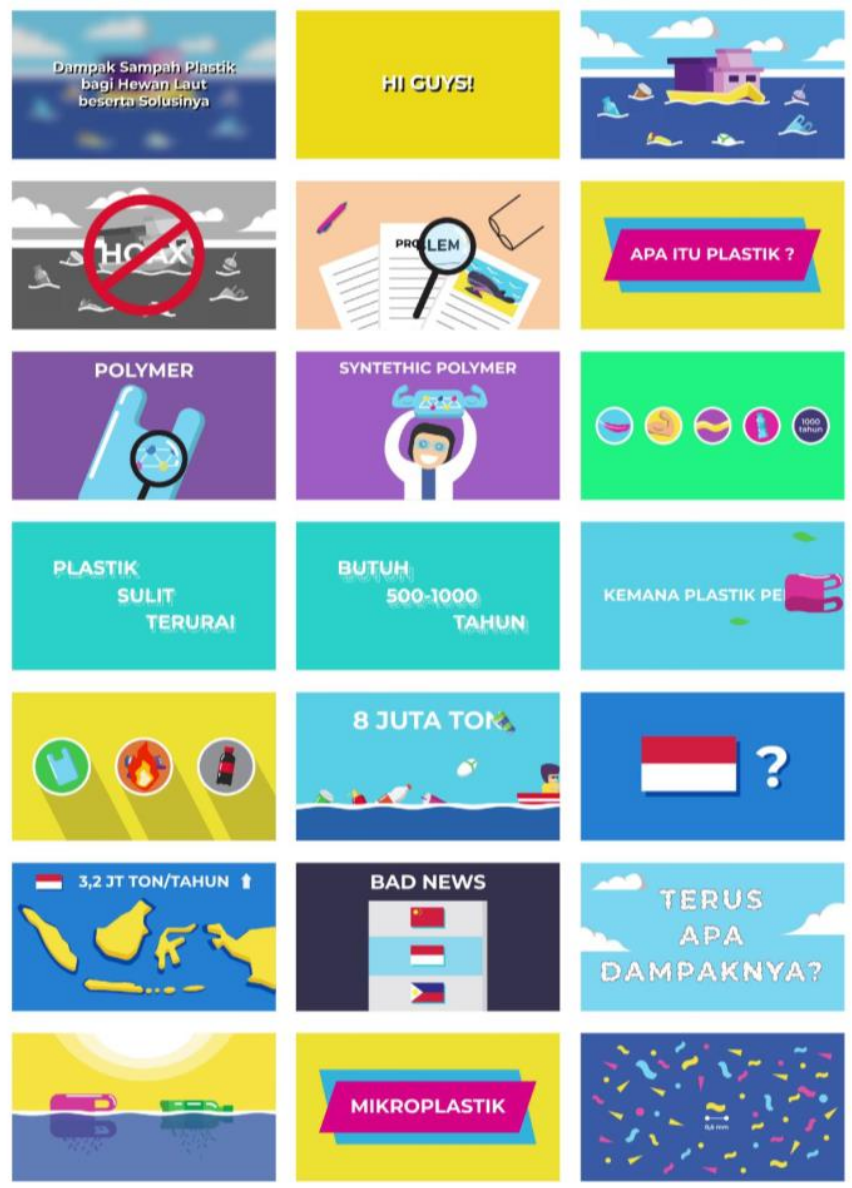

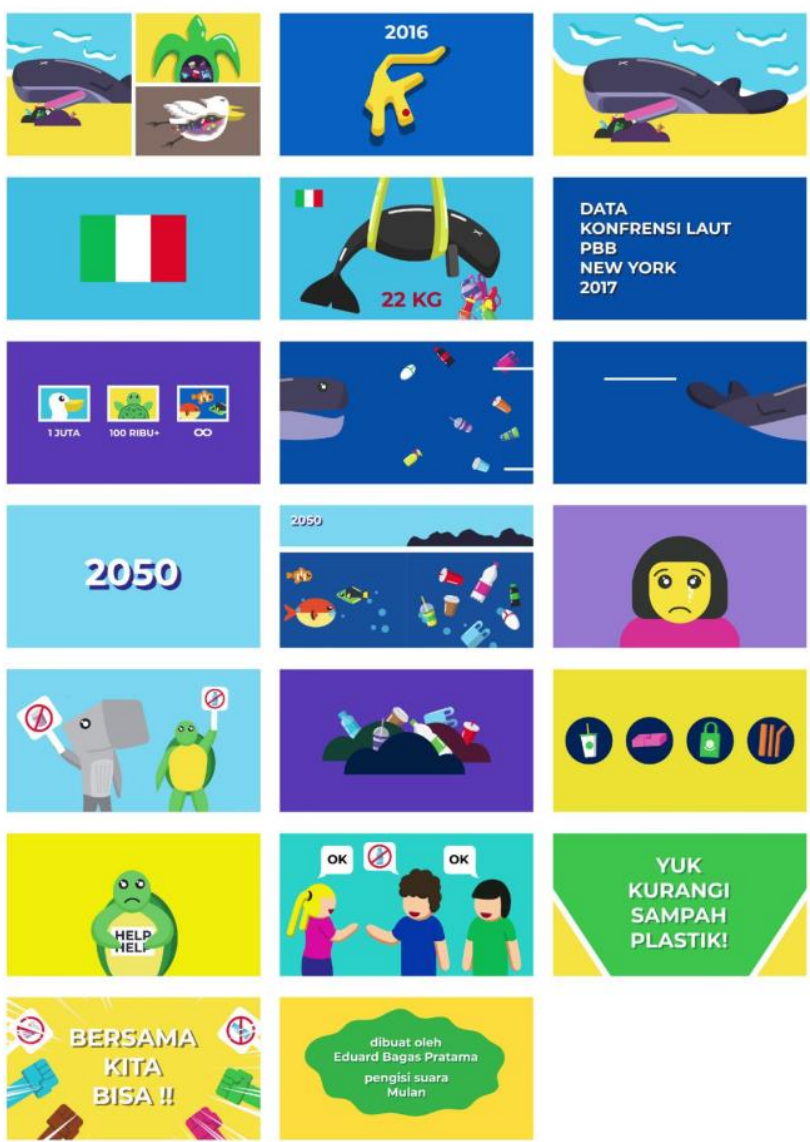

Gambar 3. Screenshoot motion graphic (Sumber: Dokumentasi penulis)

\subsubsection{Aplikasi Pada Media Pendukung: Instagram Feed}

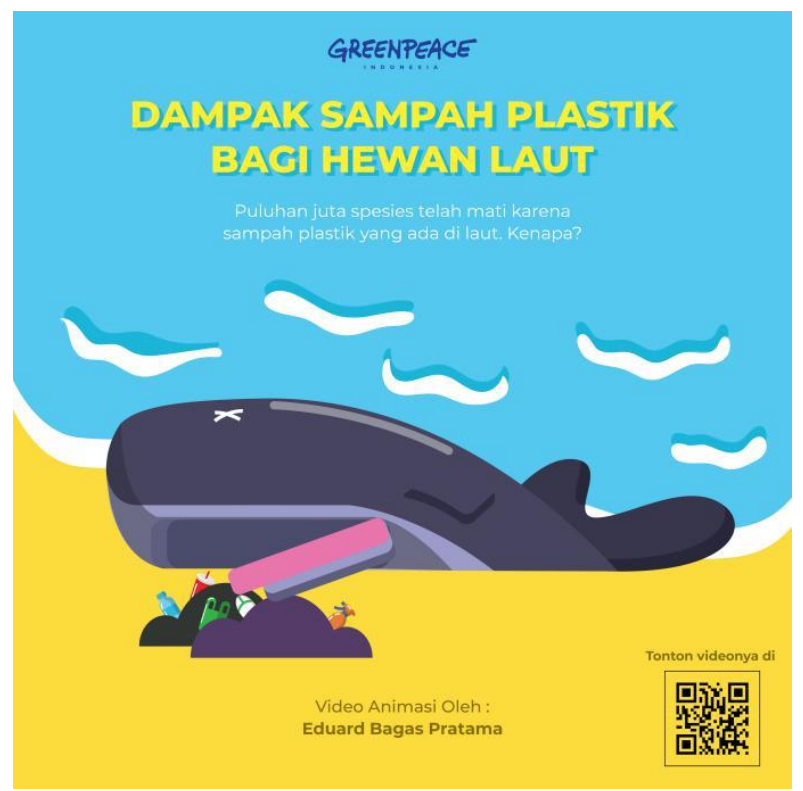

Gambar 4. Instagram feed

(Sumber: Dokumentasi penulis) 


\subsubsection{Aplikasi Pada Media Pendukung: Instagram Story (durasi 15 Detik)}
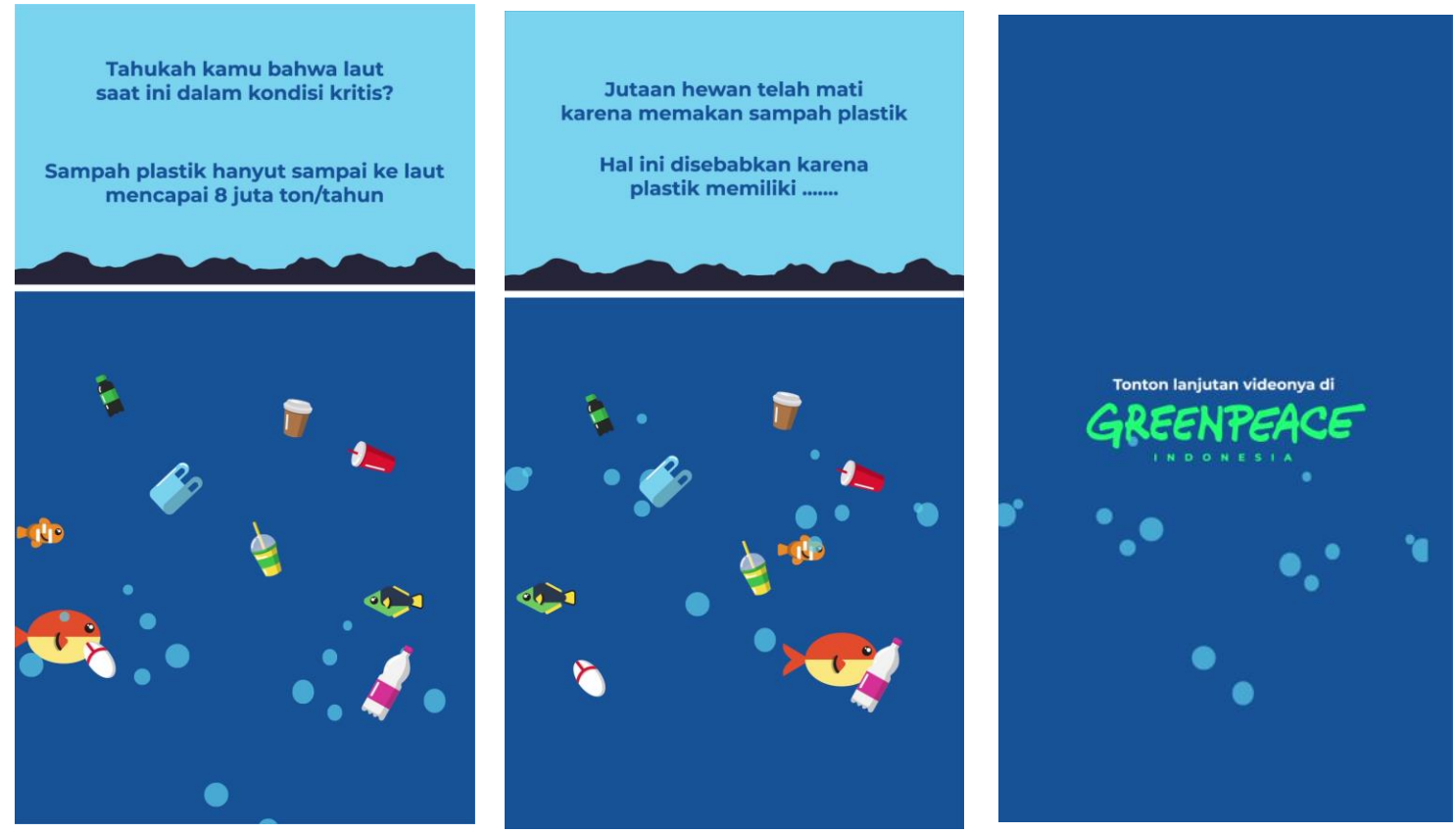

Gambar 5. Instagram Story

(Sumber: Dokumentasi penulis)

\section{KESIMPULAN}

Banyaknya sampah plastik di lautan saat ini membuat penulis tergerak untuk membuat video motion graphic mengenai dampak sampah plastik di lautan, terlebih lagi masih banyak masyarakat Indonesia yang belum sadar akan pentingnya mengurangi penggunaan plastik sekali pakai demi mendukungnya konsep "Go-Green".

Video motion graphic ini dibuat dengan tujuan untuk mengedukasi masyarakat terutama anak SMP (Sekolah Menengah Pertama) tentang dampak sampah plastik yang ada di laut yang dapat menyebabkan kerusakan ekosistem hewan-hewan di laut karena sampah plastik yang berada di laut akan langsung dimakan oleh hewan laut dan akan mati karena mereka tidak dapat mencerna plastik di dalam perut. Selain mengedukasi mengenai dampak, video ini juga menyertakan solusi yang dapat diterapkan di dalam kehidupan sehari-hari.

Anak SMP adalah target audiens yang tepat karena mereka adalah generasi muda yang dapat merubah masa depan dan menurut penelitian, di usia anak SMP yaitu 13-15 tahun, memiliki kepedulian yang tinggi terhadap lingkungan sekitar. Video motion graphic ini dibuat dengan didasari riset dan penelitian yang mendalam dari berbagai macam sumber terpercaya dan terklarifikasi agar terhindar dari asumsi dan informasi palsu. 


\section{DAFTAR PUSTAKA}

BBC News Indonesia. (2018). Paus di Wakatobi telan "115 gelas plastik" dan sandal jepit BBC News Indonesia. BBC News Indonesia.

Damayanti, \& Wulandari, H. (2018). Pengembangan Media Pembelajaran Motion Graphic Untuk Siswa Kelas XI Pada Desain Multimedia di SMKN 1 Cibadak. Jurnal Kependidikan.

Krasner, J. (2008). Motion Graphic Design Applied History and Aesthetics. In Elsevier.

Kusumadinata, A. A., Ike Atikah Ratnamulyani, \& Muhamad Rendi Nurmansyah. (2019).

Hubungan Motion Graphic Sebagai Konten Promosi Sekolah di Media Sosial.

Communications. https://doi.org/10.21009/communications.1.2.4

Mujiarto, I. (2005). Sifat dan Karakteristik Material Plastik dan Bahan Aditif. Traksi.

Prayogi R, Suryatna U, K. A. (2015). Hubungan Komunikasi Pembelajaran Sistem E-Learning Dengan Motivasi Belajar. Jurnal Komunikatio, 1(2), 99-113.

Rahmah M, Sukarelawati, F. M. (2018). Hubungan Antara Kecenderungan Mahasiswa Menggunakan Jenis Aplikasi Gadget Dengan Kepekaan Sosial. Jurnal Komunikatio, 4(2), 83-96.

Suryani, A. S. (2014). Peran Bank Sampah Dalam Efektivitas Pengelolaan Sampah (Studi Kasus Bank Sampah Malang). Aspirasi. https://doi.org/10.22212/aspirasi.v5i1.447

Utomo, Y. W. (2016). Indonesia Penghasil Sampah Plastik Kedua Terbesar di Dunia. National Geographic Indonesia.

Zettler, E. R., Mincer, T. J., \& Amaral-Zettler, L. A. (2013). Life in the "plastisphere": Microbial communities on plastic marine debris. Environmental Science and Technology. https://doi.org/10.1021/es401288x 